\title{
CIC-DUX4L Fusion Protein Expression
}

National Cancer Institute

\section{Source}

National Cancer Institute. CIC-DUX4L Fusion Protein Expression. NCI Thesaurus. Code C120221.

Expression of a fusion protein that results from a $\mathrm{t}(10 ; 19)(\mathrm{q} 26 ; \mathrm{q} 13)$ translocation, which involves the human genes $\mathrm{CIC}$ (capicua transcriptional suppressor) and DUX4L (double homeobox 4-like). 